\section{Influence of Bed Cover Types on Production Time and Quality of Sweetpotato Slips}

\author{
John C. Beaulieu ${ }^{1}$ and \\ Dyremple B. Marsh ${ }^{2}$
}

\begin{abstract}
Additional indeX words. Carver, Centennial, bed cover, growth, Jewel, Potojam, slip production, sprout production, sweetpotato, Ipomoea batatas
\end{abstract}

\begin{abstract}
Summary. Sweetpotato (Ipomoea batatas) cultivars, Carver, Potojam, Jewel and Centennial were evaluated for slip production, using topsoil, sawdust, sand and a general-purpose peat-based commercial growing media as bed covers. Temperature measured 2 inches $(5.1 \mathrm{~cm})$ below the surface of the hot bed varied with covers and date measured. Sand maintained the highest bed temperature, $77^{\circ} \mathrm{F}\left(25.0{ }^{\circ} \mathrm{C}\right)$ at $0800 \mathrm{HR}$ and $79^{\circ} \mathrm{F}\left(26.1{ }^{\circ} \mathrm{C}\right)$ at 1400 $\mathrm{HR}$, throughout the growing season. Peat-covered roots produced the maximum number of slips/plot (111), while roots covered with topsoil and sawdust produced comparable yields, 55 and 45 slips/plot, respectively. Slip production varied according to harvest date, with the third harvest producing the most slips/plot (83 and 153, in year 1 and year 2 , respectively), which, was likely related to increased temperatures. Cultivar significantly influenced number of slips, length of slips, and number of roots per slip. 'Potojam' was the most prolific slip producer for both early and mid season production under all bed covers.
\end{abstract}

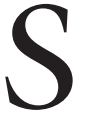
weetpotato production in central and southern Missouri is usually done by smallscale, limited-resource farmers. Market

Mention of trade names implies no endorsement by the authors, United States Department of Agriculture or Lincoln University, nor discrimination against similar products not mentioned. Research supported in part by USDA funds allocated to the University Agriculture Experiment Station.

${ }^{1}$ USDA, Agricultural Research Service, Southern Re gional Research Center, 1100 Robert E. Lee Blvd. New Orleans, LA 70124; corresponding author.

${ }^{2}$ Professor, Lincoln University Cooperative Extension, 110 Allen Hall, Box 29, Jefferson City, MO 651020029 . potential exists for profitable sweetpotato production as an alternative crop in southeastern Missouri (Wollo, 1995; Wollo and Jones, 1996). However, for midwestern U.S. farmers to compete, early spring slip production is essential. Subsequently, sweetpotato slips must be produced under suboptimal conditions. Sweetpotatoes are propagated from vine cuttings or sprouts from plant stock (roots) selected for their healthy appearance and freedom from disease and off-types. Certified roots that were properly cured $\left[85^{\circ} \mathrm{F}\left(29.4^{\circ} \mathrm{C}\right)\right.$ and about $90 \%$ to $95 \%$ relative humidity (Hardenburg et al., 1986)] are normally used for production of slips in cold frames, heated beds, or direct sprout production in field beds of clean sand or fumigated sandy soil. Under ideal presprouting conditions, roots begin developing sprouts after 4 to 5 weeks. High quality slips [i.e., numerous leaves and roots with about 6 inches $(15.2 \mathrm{~cm})$ lengths] are essential to insure an acceptable yield (Ware and McCollum, 1980) and the use of a bed cover that can maintain a favorable substrate temperature and favor early slip production is necessary. Some growers are using Pro-mix BX (Premier Horticulture, Red Hill, Pa.) as a bed cover to produce slips. The average cost of Pro-mix BX is \$14 to $\$ 16$ per $3.8 \mathrm{ft}^{3}(197 \mathrm{~L})$ uncompressed bale, potentially rendering this cover cost prohibitive for sweetpotato slip production for some growers. Turner (J.L. Turner, personal communication) observed that number and quality of slips increased with the use of pine straw, pine bark and sawdust as bed covers. In Louisiana where sprouts are produced directly in raised beds, sprout yields were comparable to numerous bed cover treatments (mulch or plastic films) later in the growing season (Walker and Randle, 1986). The primary objective of this study was to evaluate the effectiveness of several media as bed covers for early spring sweetpotato slip production grown in hot beds in Missouri. Additionally, slip yield and quality were evaluated for various cultivars commonly grown or consumed in Missouri.

\section{Materials and methods}

Hot beds were constructed similar to ones illustrated in Ware and McCollum (1980), which are similar to those used to produce slips in Missouri (Marsh and Muhammad, 1986). Soil from an area measuring $32 \times 8 \mathrm{ft}(9.7 \times$ $2.4 \mathrm{~m}$ ) was removed to a depth of 14 inches $(35.6 \mathrm{~cm})$ and lined along all sides with treated lumber measuring 2 inches $\times 12$ inches $\times 14 \mathrm{ft}(5.1 \mathrm{~cm} \times 30.5$ $\mathrm{cm} \times 4.3 \mathrm{~m}$ ). The boards were placed so that they protruded 4 inches $(10.2 \mathrm{~cm})$ above the soil level, to prevent the developing slips from coming in contact with the clear polyethylene, used to cover the entire hot bed. To ensure weed control within the hot bed, 6-mil [0.006-inch $(0.147-\mathrm{mm})]$ perforated black polyethylene was placed inside the freshly dug area and 2 inches of washed river gravel placed on top of it. A 2 -inch mesh welded wire was placed on top of the gravel. Covering of the gravel and wire was done with sand to a depth of 2.5 inches $(6.4 \mathrm{~cm})$. Heating cables were then placed 4 inches apart throughout the entire hot bed floor. Cables were connected to thermostats set to maintain a temperature of $80^{\circ} \mathrm{F}(26.7$ ${ }^{\circ} \mathrm{C}$ ) within all bed covers. The cables were covered with the bed cover [ 1 inch deep $(2.5 \mathrm{~cm})]$ to which that section of the bed was randomly assigned. Treatments were assigned in a split-plot experimental design with four replications for years 1 and 2, where bed covers were main plots and sweetpotato cultivar the subplots. Bed covers were Missouri River sand and a general-purpose peat-based (85\%) commercial growing media (Promix BX) in year 1 , and oak sawdust and topsoil (Aquic hapludalfs, fine silt loam) were added in year 2 . Sweetpotato cultivars Centennial, Jewel and Potojam were used in year 1 with the addition of 'Carver' in year 2. Main plots occupied a $64-\mathrm{ft}^{2}\left(5.9-\mathrm{m}^{2}\right)$ area with $16 \mathrm{ft}^{2}(1.5$ $\mathrm{m}^{2}$ ) allotted to each cultivar (subplot), and replicated subplots occupied $4 \mathrm{ft}^{2}$ $\left(0.4 \mathrm{~m}^{2}\right)$. In total, $55 \mathrm{lb}(24.9 \mathrm{~kg})$ of blemish free, uniform US\#l sweetpotato roots of each cultivar per replication were selected in both years. On 25 Apr. in year 1 and 14 Apr. in year 2, seed roots were dipped in a suspension of dichloran [1.6 oz/gal $\left(12 \mathrm{~g} \cdot \mathrm{L}^{-1}\right)$ a.i.] and thiabendazole $[0.45 \mathrm{fl} \mathrm{oz} / \mathrm{gal}(3.5$ $\left.\mathrm{mL} \cdot \mathrm{L}^{-1}\right)$ a.i.] in water to decrease fungal rotting in the beds. Treated roots were drained, then placed end to end in the preassigned area of the hot bed and covered to a depth of 2 inches $(5 \mathrm{~cm})$ with the assigned cover. Thermometers were placed at a depth of 2 inches within each bed cover to record bed temperature at 0800 and $1400 \mathrm{Hr}$ for the first 30 $\mathrm{d}$ after placing roots in the hot bed. Clear polyethylene was used to cover the complete bed after all treatments were applied. This cover was only re- 
moved daily when the ambient temperature was above $80^{\circ} \mathrm{F}$. During slip production, all hot bed covers were irrigated when the upper 10 inches $(25.4 \mathrm{~cm})$ throughout the bed was visually drying out.

Slips were harvested weekly by holding down the seed root with one hand and gently removing with the thumb and finger the slip from the buried roots with minimum disturbances, so as to insure continuous production over the 4-week harvest period. Slips were collected once per week (harvest date) from 16 May to 10 June in year 1 , and 9 May to 6 June in year 2 . Due to suboptimal early spring growing temperatures, a minimum slip length (from point of connection with the sprouting root to the apex of the slip's leaves) for the first harvest was established at 5 inches $(12.7 \mathrm{~cm})$. Subsequent harvests were performed when slips approached commercial harvest lengths [6.5 to 8 inches (16.5 to 20.3 $\mathrm{cm})]$. For each harvest date, the following data were recorded from subsamples of 10 slips; stem diameter 1 inch $(2.5 \mathrm{~cm})$ above the separation from the seed stock (using a linear caliper), stem length, number of fully expanded leaves, leaf area [using a LI-3100 leaf area meter (LICOR, Lincoln, Nebr.)], and slipdryweight after oven drying at $158^{\circ} \mathrm{F}\left(70^{\circ} \mathrm{C}\right)$ for 48 h. Total number of slips was also determined per cultivar (subplot).

\section{Results and discussion}

Excessive rainfall [5.9 inches (15 $\mathrm{cm}$ ) in $3 \mathrm{~d}$ ] caused flooding of the sand treatments for year 2 due to standing water in the sand layer surrounding the heating cables along a major portion of the raised bed's base. Sand plots demonstrated typical symptoms of flooding injury found to occur when flooding precedes harvesting (Collins and Wilson, 1988), and extreme restriction of sprouting resulted. Therefore, physiological data from year 2 sand plots were not included in combined (unbalanced) analyses.

There were no significant differences in the recorded bed temperatures between year 1 and year 2 ; therefore, these data (albeit, unbalanced) were combined (Table 1). Although the heating cables were set to maintain a constant bed temperature, there were variations in bed temperatures as a result of the covers used (Table 2). The highest bed temperature was maintained in the sand cover, at both 0800 and $1400 \mathrm{HR}$ (Table 1) and also in both recording periods, April and May (Table 2). While bed temperatures were similar for both the topsoil and Pro-mix covers, it was significantly lower $(P=0.05)$ for the sawdust cover. Relative temperature differences were consistently maintained among bed covers when measurements were recorded. These results suggest that media structure and available pore space play an important role in substrate temperature; permitting the bedding covers to be directly influenced by the low ambient temperatures in spring. Increase in the ambient air temperature results in an increase in the recorded bed temperatures. This resulted in the recorded temperatures for the second measuring period (May) being higher than those of the first period (April).

The number of slips and slip length were influenced by all three treatments (cover, cultivar, and date) for both years (Tables 3 and 4). Number of roots per slip was affected by date and cultivar in both years and by cover in year 2 only (Table 4). There were significant interactive effects between date and cover for the number of slips produced in year 2 (Table 4). However, there were no significant date $\times$ cover $\times$ cultivar interactions in both years. This indicates that while cover and date influenced the number of slips, the influence was the same for all cultivars. Bed cover response was more apparent with regards to the number of slips at the later harvest dates (Table 3 ).

Slip yield (no.) was reduced in year 2 compared to year 1 (Table 5 ). However, Pro-mix maintained the highest slip production in both years. In year 2 , although not significantly different, slip

Table 1. Time $\times$ bed cover interaction effects for combined (years 1 and 2 ) temperature $\left({ }^{\circ} \mathrm{C}\right)^{\mathrm{z}}$ recorded at the 2 -inch $(5.1-\mathrm{cm})$ depth within the hot bed for the first $30 \mathrm{~d}$ after placing sweetpotato roots.

\begin{tabular}{lccccc}
\hline Time & \multicolumn{5}{c}{ Bed cover $^{\mathrm{y}}$} \\
\cline { 2 - 5 }$(\mathbf{H R})$ & Sand & Sawdust & Pro-mix & Topsoil & Avg \\
\hline 0800 & $25.0 \mathrm{c}$ & $13.9 \mathrm{a}^{* *}$ & $17.6 \mathrm{~b}^{* *}$ & $17.6 \mathrm{~b}^{* *}$ & $18.5^{* *}$ \\
1400 & $26.1 \mathrm{c}$ & $18.2 \mathrm{a}$ & $22.4 \mathrm{~b}$ & $21.1 \mathrm{~b}$ & 21.9 \\
Average & $25.6 \mathrm{c}$ & $16.0 \mathrm{a}$ & $20.0 \mathrm{~b}$ & $19.3 \mathrm{~b}$ & \\
\hline
\end{tabular}

${ }^{\mathrm{z}} \mathrm{F}=1.8\left({ }^{\circ} \mathrm{C}\right)+32$.

y Mean separation followed by the same letter within rows are not significantly different by least significant difference $P \leq 0.05$.

*,** Significant at $P \leq 0.05$ and 0.01 , respectively, within columns.

Table 2. Date $\times$ bed cover interaction effects for combined (years 1 and 2) temperature $\left({ }^{\circ} \mathrm{C}\right)^{\mathrm{z}}$ recorded at the 2 inch $(5 \mathrm{~cm})$ depth within the hot bed for the first $30 \mathrm{~d}$ after placing sweetpotato roots.

\begin{tabular}{lccccc}
\hline & \multicolumn{4}{c}{ Bed cover $^{\mathbf{~}}$} \\
\cline { 2 - 5 } Date & Sand & Sawdust & Pro-mix & Topsoil & Avg \\
\hline April & $19.8 \mathrm{c}^{* *}$ & $12.2 \mathrm{a}^{* *}$ & $16.9 \mathrm{~b}^{* *}$ & $15.2 \mathrm{~b}^{* *}$ & $16.1^{* *}$ \\
May & $31.3 \mathrm{c}$ & $19.8 \mathrm{a}$ & $23.1 \mathrm{~b}$ & $23.6 \mathrm{~b}$ & 24.5 \\
Average & $25.6 \mathrm{c}$ & $16.0 \mathrm{a}$ & $20.0 \mathrm{~b}$ & $19.4 \mathrm{~b}$ & \\
\hline
\end{tabular}

${ }^{\mathrm{Z}} \mathrm{F}=1.8\left({ }^{\circ} \mathrm{C}\right)+32$.

y Mean separation followed by the same letter within rows are not significantly different by least significant difference $P \leq 0.05$.

${ }^{*, * *}$ Significant at $P \leq 0.05$ and 0.01 , respectively, within columns.

Table 3. Number of sweetpotato slips produced under different bed covers by harvest date (year 2 only).

\begin{tabular}{lccrcc}
\hline & \multicolumn{5}{c}{ Slips produced(no.) } \\
\cline { 2 - 5 } Cover & $\mathbf{5}$ & $\mathbf{2}$ & $\mathbf{3}$ & $\mathbf{4}$ & Avg \\
\cline { 2 - 5 } & $11.3 \mathrm{a}$ & $42.2 \mathrm{ab}$ & $59.4 \mathrm{~b}$ & $67.0 \mathrm{~b}$ & 49.9 \\
Sawdust & $20.4 \mathrm{a}$ & $88.0 \mathrm{~b}^{\text {** }}$ & $106.1 \mathrm{~b}^{* *}$ & $81.3 \mathrm{~b}$ & $73.9^{*}$ \\
Pro-mix & $13.6 \mathrm{a}$ & $37.0 \mathrm{a}$ & $82.6 \mathrm{~b}^{*}$ & $87.1 \mathrm{~b}$ & 53.1 \\
Topsoil & $17.8 \mathrm{a}$ & $61.2 \mathrm{~b}$ & $83.4 \mathrm{c}$ & $78.4 \mathrm{c}$ & \\
Average & & &
\end{tabular}

${ }^{\mathrm{z}}$ Mean separation followed by the same letter within rows are not significantly different by least significant difference at $P \leq 0.05$

yOnce slips attained roughly 5 inches $(12.7 \mathrm{~cm})$, they were harvested weekly for 4 weeks (harvest dates $1-4)$ from 9 May to 6 June.

${ }^{*},{ }^{* *}$ Significant at $P \leq 0.05$ and 0.01 , respectively, within columns. 
Table 4. Analysis of variance for sweetpotato slip measurements as influenced by bed covers (C), date (D), and cultivar (V).

\begin{tabular}{|c|c|c|c|c|c|c|c|c|}
\hline \multirow[b]{2}{*}{ Source } & \multirow[b]{2}{*}{ df } & \multicolumn{7}{|c|}{ Measurement } \\
\hline & & $\begin{array}{c}\text { No.of } \\
\text { slips/bed }\end{array}$ & $\begin{array}{l}\text { Sliplength } \\
\text { (cm) }\end{array}$ & $\begin{array}{c}\text { No. of } \\
\text { roots }\end{array}$ & $\begin{array}{l}\text { Stem } \\
\text { diam }\end{array}$ & $\begin{array}{l}\text { No. of } \\
\text { leaves }\end{array}$ & $\begin{array}{l}\text { Leaf } \\
\text { area }\end{array}$ & $\begin{array}{c}\text { Dry } \\
\text { wt }\end{array}$ \\
\hline C & 1 & * & ** & NS & NS & NS & NS & NS \\
\hline $\mathrm{D}$ & 3 & ** & ** & * & ** & NS & NS & NS \\
\hline $\mathrm{V}$ & 2 & ** & ** & ** & $* *$ & NS & NS & * \\
\hline $\mathrm{D} \times \mathrm{V}$ & 6 & NS & NS & NS & NS & NS & NS & NS \\
\hline $\mathrm{D} \times \mathrm{V} \times \mathrm{C}$ & 6 & NS & NS & NS & NS & NS & NS & NS \\
\hline Error & 22 & & & & & & & \\
\hline \multicolumn{9}{|l|}{ Year 2} \\
\hline C & 2 & ** & ** & * & NS & NS & NS & NS \\
\hline $\mathrm{D} \times \mathrm{V}$ & 9 & NS & NS & NS & NS & NS & NS & NS \\
\hline $\mathrm{D} \times \mathrm{V} \times \mathrm{C}$ & 18 & NS & NS & NS & NS & NS & NS & NS \\
\hline Error & 109 & & & & & & & \\
\hline
\end{tabular}

\footnotetext{
ss, ${ }^{\star \star *}$ Nonsignificant or significant at $P \leq 0.05$ or 0.01 , respectively, within columns.
}

yields in sawdust covers were less than those produced in topsoil. Sawdust is the cover most frequently used in the southern United States and is sometimes recommended for use in Missouri (Marsh and Muhammad, 1986). In addition to slip yield, the quality of slip is very important. Pro-mix was superior to sawdust and topsoil in producing good quality slips, as measured by slip length and number of roots per slip, in year 2 (Table 5). Slip length was also superior in Pro-mix compared to sand in year 1 (Table 5). Harvesting of slips from soil-covered roots was very difficult and frequently resulted in damage that may have contributed to a lower number of roots per slip, and lower overall slip yield under this cover.

Early production of slips provides the opportunity for early planting of sweetpotato, and early planting of slips is known to improve yields by allowing the crop to mature before the onset of unfavorable hot summer days (Sajjapongse et al., 1988). In this study, slip harvest date influenced both number and quality of slips (Table 5 ). In both year 1 , and year 2 there was a linear increase in number of slips produced up to the third harvest date (combined linear averages, with the intercept set to $0 ; R^{2}=0.86$ for topsoil, 0.88 for Promix and 0.93 for sawdust), after which number of slips produced occasionally declined (e.g., Table 3). Sweetpotato slips were longer and had more roots as
Table 5. Main effects of bed cover, date and cultivar for sweetpotato slip production as influenced by bed covers, date, and cultivar.

\begin{tabular}{|c|c|c|c|c|}
\hline $\begin{array}{l}\text { Main } \\
\text { effects }\end{array}$ & $\begin{array}{c}\text { Slips } \\
\text { (no./bed) }\end{array}$ & $\begin{array}{c}\text { Sliplength } \\
(\mathrm{cm})^{\mathrm{z}}\end{array}$ & $\begin{array}{c}\text { Roots } \\
\text { (no.) }\end{array}$ & $\begin{array}{c}\text { Stem diam } \\
(\mathrm{cm})\end{array}$ \\
\hline \multicolumn{5}{|l|}{ Year 1} \\
\hline \multicolumn{5}{|l|}{ Cover } \\
\hline Sand & $92.5 \mathrm{a}^{\mathrm{y}}$ & $16.5 \mathrm{a}$ & $24.0 \mathrm{a}$ & $0.3 \mathrm{a}$ \\
\hline Pro-mix & $110.8 \mathrm{~b}$ & $19.7 \mathrm{~b}$ & $22.6 \mathrm{a}$ & $0.3 \mathrm{a}$ \\
\hline \multicolumn{5}{|l|}{ Cultivar } \\
\hline Centennial & $109.4 \mathrm{~b}$ & $16.8 \mathrm{a}$ & $26.9 \mathrm{~b}$ & $0.3 \mathrm{~b}$ \\
\hline Jewel & $77.3 \mathrm{a}$ & $17.6 \mathrm{~b}$ & $18.2 \mathrm{a}$ & $0.2 \mathrm{a}$ \\
\hline Potojam & $118.4 \mathrm{~b}$ & $19.9 \mathrm{c}$ & $24.8 \mathrm{~b}$ & $0.3 \mathrm{~b}$ \\
\hline \multicolumn{5}{|l|}{ Date $^{x}$} \\
\hline 1 & $35.7 \mathrm{a}$ & $13.7 \mathrm{a}$ & $18.5 \mathrm{a}$ & $0.3 \mathrm{~b}$ \\
\hline 2 & $93.9 \mathrm{~b}$ & $17.1 \mathrm{~b}$ & $21.5 \mathrm{ab}$ & $0.3 \mathrm{~b}$ \\
\hline 3 & $153.1 \mathrm{~d}$ & $22.2 \mathrm{c}$ & $26.9 \mathrm{c}$ & $0.3 \mathrm{~b}$ \\
\hline 4 & $124.1 \mathrm{c}$ & $19.3 \mathrm{~b}$ & $26.2 \mathrm{bc}$ & $0.2 \mathrm{a}$ \\
\hline \multicolumn{5}{|l|}{ Year 2} \\
\hline \multicolumn{5}{|l|}{ Cover } \\
\hline Sawdust & $44.9 \mathrm{a}$ & $19.6 \mathrm{~b}$ & $18.6 \mathrm{~b}$ & $0.6 \mathrm{a}$ \\
\hline Pro-mix & $73.9 \mathrm{~b}$ & $21.1 \mathrm{c}$ & $19.8 \mathrm{~b}$ & $0.3 \mathrm{a}$ \\
\hline Topsoil & $55.0 \mathrm{a}$ & $18.2 \mathrm{a}$ & $15.8 \mathrm{a}$ & $0.4 \mathrm{a}$ \\
\hline \multicolumn{5}{|l|}{ Cultivar } \\
\hline Carver & $52.4 \mathrm{~b}$ & $18.4 \mathrm{a}$ & $13.4 \mathrm{a}$ & $0.4 \mathrm{a}$ \\
\hline Centennial & $36.2 \mathrm{a}$ & $19.7 \mathrm{ab}$ & $24.1 \mathrm{c}$ & $0.3 \mathrm{a}$ \\
\hline Jewel & $67.9 \mathrm{c}$ & $21.0 \mathrm{~b}$ & $18.4 \mathrm{~b}$ & $0.4 \mathrm{a}$ \\
\hline Potojam & $75.4 \mathrm{c}$ & $19.4 \mathrm{a}$ & $16.2 \mathrm{ab}$ & $0.7 \mathrm{a}$ \\
\hline \multicolumn{5}{|l|}{ Date } \\
\hline 1 & $15.1 \mathrm{a}$ & $16.9 \mathrm{a}$ & $15.4 \mathrm{a}$ & $0.7 \mathrm{a}$ \\
\hline 2 & $55.7 \mathrm{~b}$ & $20.3 \mathrm{bc}$ & $17.6 \mathrm{~b}$ & $0.4 \mathrm{a}$ \\
\hline 3 & $82.7 \mathrm{c}$ & $21.4 \mathrm{c}$ & $18.4 \mathrm{~b}$ & $0.3 \mathrm{a}$ \\
\hline 4 & $78.4 \mathrm{c}$ & $19.7 \mathrm{~b}$ & $20.7 \mathrm{~b}$ & $0.3 \mathrm{a}$ \\
\hline
\end{tabular}

$1.0 \mathrm{~cm}=0.39$ inch.

${ }^{\mathrm{y}}$ Mean separation within main effects in columns followed by the same letter are not significantly different by least significant difference at $P \leq 0.05$.

${ }^{x}$ Once slips attained roughly 5 inches $(12.7 \mathrm{~cm}$ ), they were harvested weekly for 4 weeks (harvest dates $1-4)$ from 16 May to 10 June in year 1 and 9 May to 6 June in year 2 . 